\title{
ANXIETY LEVEL ANALYSIS OF NURSING STUDENT WHO TOOK OBJECTIVE STRUCTURED CLINICAL EXAMINATION (OSCE) USING FACE TEMPERATURE DISTRIBUTION BASED ON THERMAL IMAGING
}

\author{
Ni Made Dian Sulistiowati", Wayan Nata Septiadi**, Luh Putu Nopriani* \\ ${ }^{*}$ School of Nursing, Faculty of Medicine, Udayana University \\ ** Department of Mechanical engineering, faculty of engineering Udayana University \\ Email : sulistiowati.md@unud.ac.id
}

\begin{abstract}
ABSTRAK
Pendahuluan: Stres dapat mempengaruhi berbagai fungsi sistem organ dalam tubuh manusia, terutama sistem kardiovaskular. Stres berkepanjangan dapat muncul sebagai kecemasan. Tujuan dari penelitian ini adalah untuk memeriksa suhu wajah siswa keperawatan yang mengalami kecemasan sebelum OSCE. Metode: Desain penelitian ini adalah pra eksperimental. Distribusi suhu wajah sampel yang mengalami kecemasan terlihat menggunakan thermal imaging. Sampel dalam penelitian ini terdiri dari 81 siswa program keperawatan di Universitas Udayana yang mengambil OSCE yang dipilih dengan teknik total sampling. Instrumen penelitian ini adalah GAD 7 yang terdiri dari 7 item pertanyaan. Instrumen ini diadministrasikan sebelum suhu diukur. Hasil: Hasil penelitian ini menunjukkan bahwa siswa perawat mengalami kecemasan ringan, dimana $49 \%$ dan $15 \%$ di antaranya berurutan di bawah suhu normal dan suhu normal di depan kepala. Sementara 33\% dan 2\% siswa keperawatan berurutan berada di bawah suhu normal dan suhu normal di atas pada sisi temporal kepala. Ada perbedaan pada setiap tingkat kecemasan yang diukur pada sisi temporal dan frontal kepala $(\mathrm{p}=.001)$. Diskusi: Tingkat kecemasan ringan hingga parah terjadi saat suhu sedang meningkat. Studi yang berkaitan dengan thermal imaging di bagian tubuh lain harus dilakukan untuk mengetahui perbedaan perubahan pada bagian lain suhu tubuh.
\end{abstract}

Kata kunci:

\section{ABSTRACT}

Introduction: Stress could affect various organ system functions in the human body, especially cardiovascular system Prolonged stress could appear as anxiety. The aim of this study is to examine the face temperature of the nursing student who experienced anxiety before OSCE. Method: Design of this study is pre-experimental. Face temperature distribution of the sample who experienced anxiety was seen using thermal imaging. A sample of this study consist of 81 students of nursing school program of UdayanaUniversity who took OSCE that was chosen by total sampling technique. The instrument of this study is GAD 7 that consists of 7 question items. This instrument was administrated before the temperature measured. Result: Result of this study shows that 81 nursing students experienced mild anxiety, where 49\% and $15 \%$ of them consecutively have under normal temperature and normal upper temperature at frontal side of the head. While $33 \%$ and $2 \%$ nursing students consecutively have under normal temperature and normal upper temperature at temporal side of the head. There is a difference in each anxiety level that was measured in a temporal and frontal side of the head $(p=.001)$. Discussion: Mild until severe anxiety level happens when the temperature is increasing. Studies related to thermal imaging in another part of the body should be conducted to know the differences of the changes in another part of body temperature.

Keywords: thermal imaging, anxiety, face temperature

\section{INTRODUCTION}

Generalized anxiety disorder (GAD) is an anxiety disorder that commonly found in the clinic, estimated $12 \%$ from all kind of anxiety disorder. Its prevalence in Indonesia is not certainly known, but it was estimated $2 \%-5 \%$ (Iskandar,1994). GAD more often experienced by female than male (ratio 2:1), but the ratio between the male and female who access health care services is same (1:1) (Kaplan, 1994). There are three main neurotransmitters that correlate with anxiety, that is: norepinephrine (NE), serotonin and gamma amino butyric. Norepineprinsystem controlled fight-flight responses in human. NE located on the locus ceruleous in the brain. NE connected to the neurotransmitter to the other structure of the brain that correlated with anxiety part in the brain such as the amygdala, hippocampus and cerebral cortex (thinking, interpreting,dan planning).Therefore, a nurse has to able to use psychopathology nursing approach based on 
nursing process, psychodynamic of mental health disorder (Stuart \&Laraia, 2005) and stage of human development (Erik Erikson). Nurses have to detect patient's anxiety accurately and quickly.

Thermal imaging is a method that could increasing object visibility in the dark through repeated reflection and infrared detection of the object and change that condition to a shape of a color degraded picture based on the information that was received by the sensor (Lloyd, J. M., 2013). Thermal imaging could provide more high-quality pictures quickly without any risk. Thermal imaging provides information about the intervention procedure that was shown as a temperature distribution pictures. This study will examine the difference of temperature distribution at university student face who experience anxiety at a different level.

\section{METHODE}

This study using quantitative design with an experimental method. The sample of this study consists of 81 students of nursing school program of Udayana University who took OSCE that was chosen by total sampling technique. The instrument of this study is GAD 7 that consists of 7 question items. This instrument was administrated to the sample before the temperature measured. After the instruments have administered, researchers measured the temporalis and frontal temperature of the sample using thermal imaging. The data were analyzed with Spearman test correlation.

\section{RESULTS}

Graphic 1 shows that the level anxiety with a temperature of the frontal side of the head measured by thermal imaging that under normal temperature range is $7 \%, 15 \%$ that students experienced consecutively no anxiety and mild anxiety. While upper normal temperature range is $9 \%, 49 \%, 21 \%$ that students experienced consecutively no anxiety, mild anxiety and moderate anxiety.
Graphic 2 shows that the level anxiety with a temperature of the frontal side of the head measured by thermal imaging that under normal temperature is $2 \%, 2 \%$ that students experienced consecutively no anxiety and mild anxiety. While at normal upper temperature are $6 \%, 33 \%, 10 \%$ that students experienced consecutively no anxiety, mild anxiety and moderate anxiety. There is a different level of anxiety that was measured in a temporal and frontal side of the head (P .001).

\section{DISCUSSION}

Thermal imaging is a method that could increasing object visibility in the dark through repeated reflection and infrared detection of the object and change that condition to a shape of a color degraded picture based on the information that was received by the sensor (Lloyd, J.M., 2013). Thermal imaging detects heat or distribution of the object's temperature by gathering all of the infrared radiations from

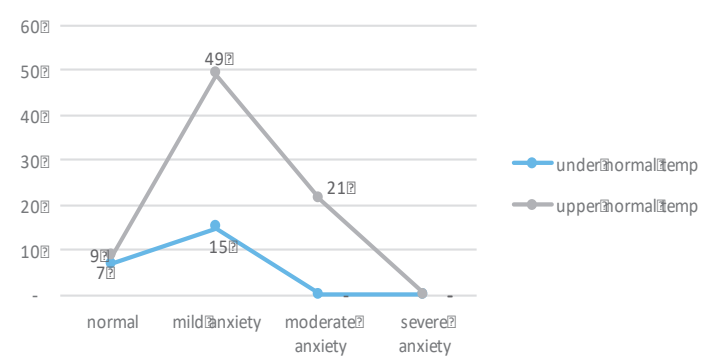

Graphic 1. Distribution of Level Anxiety with Temperature of The Frontal Side of The Head Measured by Thermal Imaging

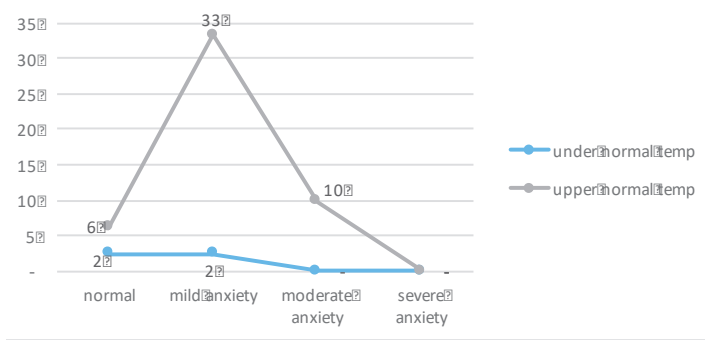

Graphic 2. Distribution of Level Anxiety with Temperature of The Temporal Side of The Head Measured by Thermal Imaging 
the object and changes it to electronic picture based on the temperature differences.

The result of this study shows that, if the frontal temperature is increased from the normal range, all university students as a sample in this study experienced anxiety (from mild to severe anxiety). If the temporalis temperature is increased from the normal range, all university students also experience anxiety (from moderate to severe anxiety). While if the temperature of frontal and temporalis in the normal range, university students are experienced no anxiety/normal and mild anxiety.

Measurement of body temperature is more effective way to detect anxiety. Thermal imaging is one method that can be used to deal with this. Thermal imaging is simple, noninvasive, and could provide the result quickly. Thermal imaging has been used in burn injury. Thermal imaging could diagnose burn injury effectively (Renkielska et al., 2006). Thermal imaging also detected the depths of the burn injury accurately (Hardwicke, 2012). Thermal cameras could provide high-quality pictures quickly and easy to use. Thermal imaging could provide more subtle image than LDI. It makes easier to make classification in superficial partial thickness burn, or skin without burn injury, especially if it was surrounded by a deeper burn injury.

Although some studies have been proved that thermal imaging could give many benefits in health care, we suggest that studies related to thermal imaging in another part of the body should be conducted to know the differences of the changes in another part of body temperature. Further studies about the most appropriate body part that could provide most accurate result also have to conduct. Therefore, we recommend further studies able to address this problem and comparing some body parts temperatures to detect anxiety.

\section{CONCLUSION}

Our result suggests that the increase in body temperature at the temporalis and frontal side of the respondent's head correlate with the increase of the anxiety level of the respondent.

\section{ACKNOWLEDGMENT}

We would like to thank PSIK FK Udayana, nursing school program of Udayana University, for allowing us to conduct this study. This work was supported by AIPNI through AINEC 2016 project.

\section{REFERENCES}

Carlak, H. F., Gencer, N. G., \& Besikci, C. (2016). Theoretical assessment of electrothermal imaging: A new technique for medical diagnosis. Infrared Physics \& Technology, 76, 227-234.

Hardwicke, J., Thomson, R., Bamford, A., \&Moiemen, N. (2013). A pilot evaluation study of high resolution digital thermal imaging in the assessment of burn depth. Burns, 39(1), 76-81.

Iskandar Y (1994). Mengatasi Anxietas, Yayasan Dharma Graha

Kaczmarek, M. (2016). A new diagnostic IR-thermal imaging method for evaluation of cardiosurgery procedures. Biocybernetics and Biomedical Engineering, 36(2), 344354.

Kaplan \& Sadock. (1997) Kaplan dan Sadock: Sinopsis Psikiatri: ilmu pengetahuan psikiatri klinis. (Jilid 1). Jakarta: Bina Rupa Aksara

Lloyd, J. M. (2013). Thermal imaging systems. Springer Science \& Business Media.

Nieuwenhoff, M. D., Wu, Y., Huygen, F. J. P. M., Schouten, A. C., van der Helm, F. C. T., \& Niehof, S. P. (2016). Reproducibility of axon reflex-related vasodilation assessed by dynamic thermal imaging in healthy subjects. Microvascular research, 106, 1-7.

Renkielska, A., Nowakowski, A., Kaczmarek, M., \& Ruminski, J. (2006). Burn depths evaluation based on active dynamic IR thermal imaging - a preliminary study. Burns, 32(7), 867-875.

Stuart \& Laraia. (2005). Principles and Practice of psychiatric nursing. (7th edition). St Louis: Mosby 